\title{
Holocene changes in the conditions of sedimentation in the eastern part of Lake Jamno based on sediment profile JS-64
}

\author{
Bartosz Bieniek \\ Geology and Palaeogeography Department, Faculty of Geosciences, University of Szczecin, Mickiewicza 18, 70-383 Szczecin, Poland \\ e-mail: bartosz.bieniek@univ.szczecin.pl
}

\begin{abstract}
Changes in sedimentological conditions in Lake Jamno during its development throughout the Holocene are presented in this paper. For this purpose, selected granulometric and geochemical parameters were used, which describe the nature and dynamics of the environment, as well as determining primary production capacity and origin of the matter. On the basis of these parameters, the environmental conditions occurring in subsequent stages of lake development were distinguished.
\end{abstract}

Key words: lake sediments, Lake Jamno, particle size analysis

\section{Introduction}

Changes in sea level during the Holocene played a key role in the creation of lakes along the Polish coast. They left a record in the form of sediment series, which were being created in subsequent stages of development. On the basis of information provided by sedimentological research, a reconstruction of former sedimentation environments can be carried out and lithodynamical processes that determine them can be recognised. This is possible by grain size distribution parameters of the sediment, which together with data on the amount and origin of organic matter as well as with information on the age of a particular series allow the nature of changes to be determined and their rate and dynamics in particular development phases of the investigated water body to be followed (Racinowski et al. 2001; Osadczuk 2004; Borówka 2007).

Jamno Lake is a one of the largest coastal lakes in Poland. Its development is associated with water entering swampy and lacustrine lowlands. According to present research, the ingression took place during Littorina Transgression ca. $6710 \pm 50$ years BP (7659-7486 cal. BP), which resulted in the creation of either an open sea bay or lagoon. Next, this water body was separated from the open sea by a southwardly developing spit over time. In such a configuration, where the water body was cut off from the influence of sea water, a water freshening process commenced and the impact of sea waters was limited to storm events only (Przybyłowska-Lange 1979; Dąbrowski et al. 1985; Borówka 2002; Miotk-Szpiganowicz et al. 2007; Bieniek et al. 2013).

\section{Materials and methods}

Research material used in this article was derived from a core section of $1.8 \mathrm{~m}$ length and marked as JS-64, which is located in the north-eastern part of Lake Jamno (Fig. 1). The core was taken as a part of the project entitled: "Verification and reinterpretation of results of studies on lacustrine sediments contaminated by heavy metals, nutrients and organic compounds along with drawing up of the unified methodology within this scope on the basis of sediments analyses of lake and dammed reservoirs which are in need of starting their revitalisation based on studies carried out at selected water bodies - pilot study" implemented in 2009. 


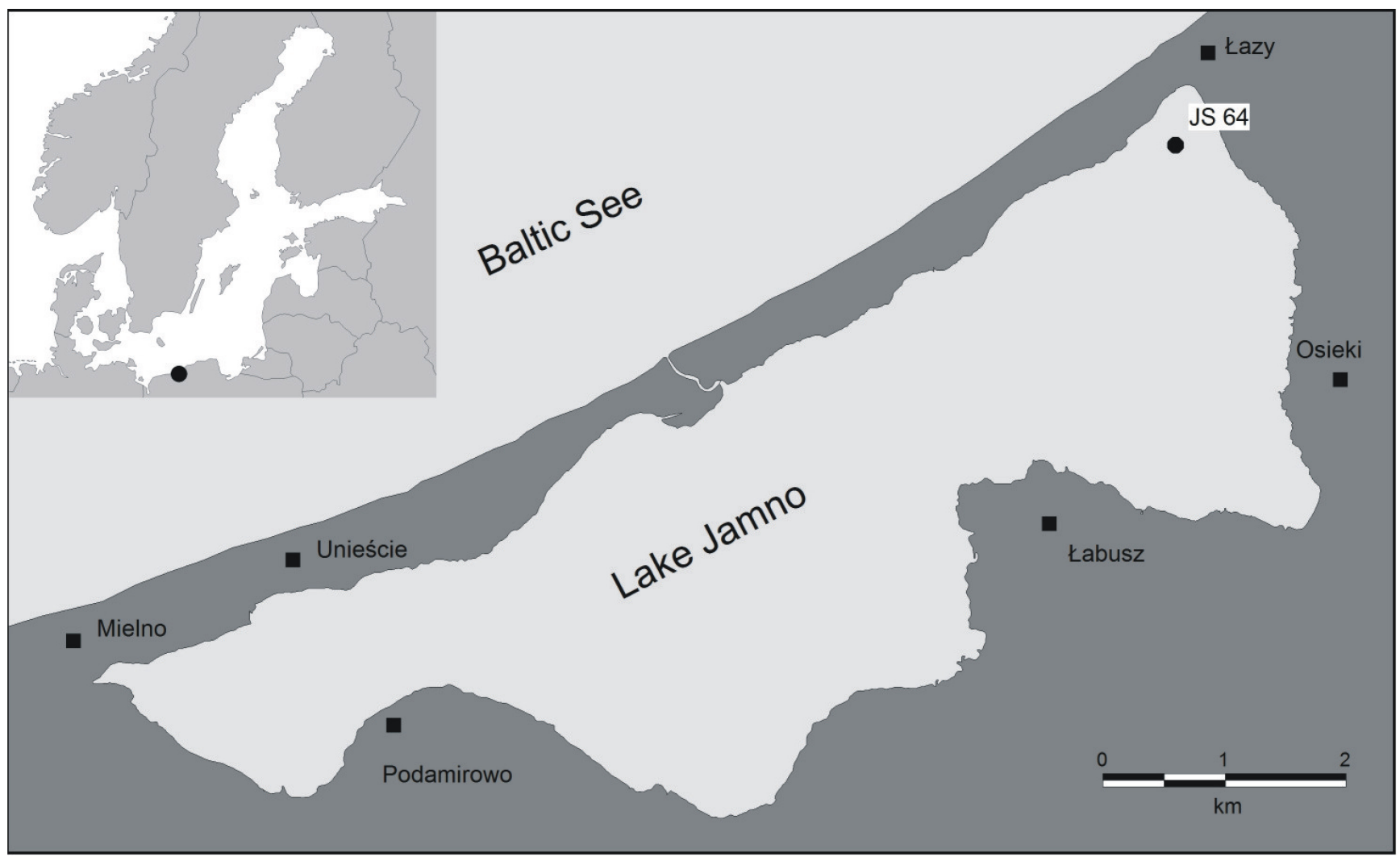

Fig. 1. Location of JS-64 core

The obtained sediment was examined in terms of organic matter content through loss of ignition, nutrient element content $(\mathrm{C}, \mathrm{N}, \mathrm{S})$ by means of VarioMAX CNS element analyser manufactured by the Elementar company and $\mathrm{CaCO}_{3}$ content through the Scheibler method. Grain size distribution analysis was carried out using a set of sieves of mesh gradation every 0.5 phi and a Mastersizer TM particle size analyser provided by the Malvern company.

Sedimentological conditions were determined on the basis of the results obtained, deploying grain size distribution parameters according to equations suggested by Folk and Ward (1957), whereas changes in sedimentological settings and the sediment transportation mechanism were set out using the Passega C-M diagram (Passega and Byramjee 1969).

The origin of organic matter and changes in primary production were determined by means of the parameter $\mathrm{OC} / \mathrm{N}$, which is an organic carbon (OC) to nitrogen $(\mathrm{N})$ ratio. Radiocarbon datings were carried out for two macroremains samples, two sediment samples and two Cardium glaucum samples, in order to determine the stratigraphy of selected sediment se- ries. These examinations were performed at Poznań Radiocarbon Laboratory.

The results obtained were further investigated by cluster analysis using Ward's method and Euclidean distances, which in combination with macroscopic features of the core section allowed stages characterised by different sedimentological conditions of the environment to be distinguished (Fig. 2).

\section{Results}

Up to a depth of $1.72 \mathrm{~m}$ below bottom level, the examined core is composed of light blue, clayey silt that contains single plant remains in the uppermost part (Fig. 3). This sediment represents lacustrine, pre-Littorina series (Ia) of low organic matter content $(2.4 \%)$, low nutrient content $(\mathrm{C}, \mathrm{N}, \mathrm{S})$, which is $0.27 \%, 0.04 \%$ and $0.07 \%$ respectively and absence of calcium carbonate. Mean grain diameter is 4.14 phi and the sediment is characterised by positively skewed and mesokurtic distribution. The low carbon-nitrogen ratio indicates an autogenic origin of organic matter, whereas grain size distribution parameters suggest 


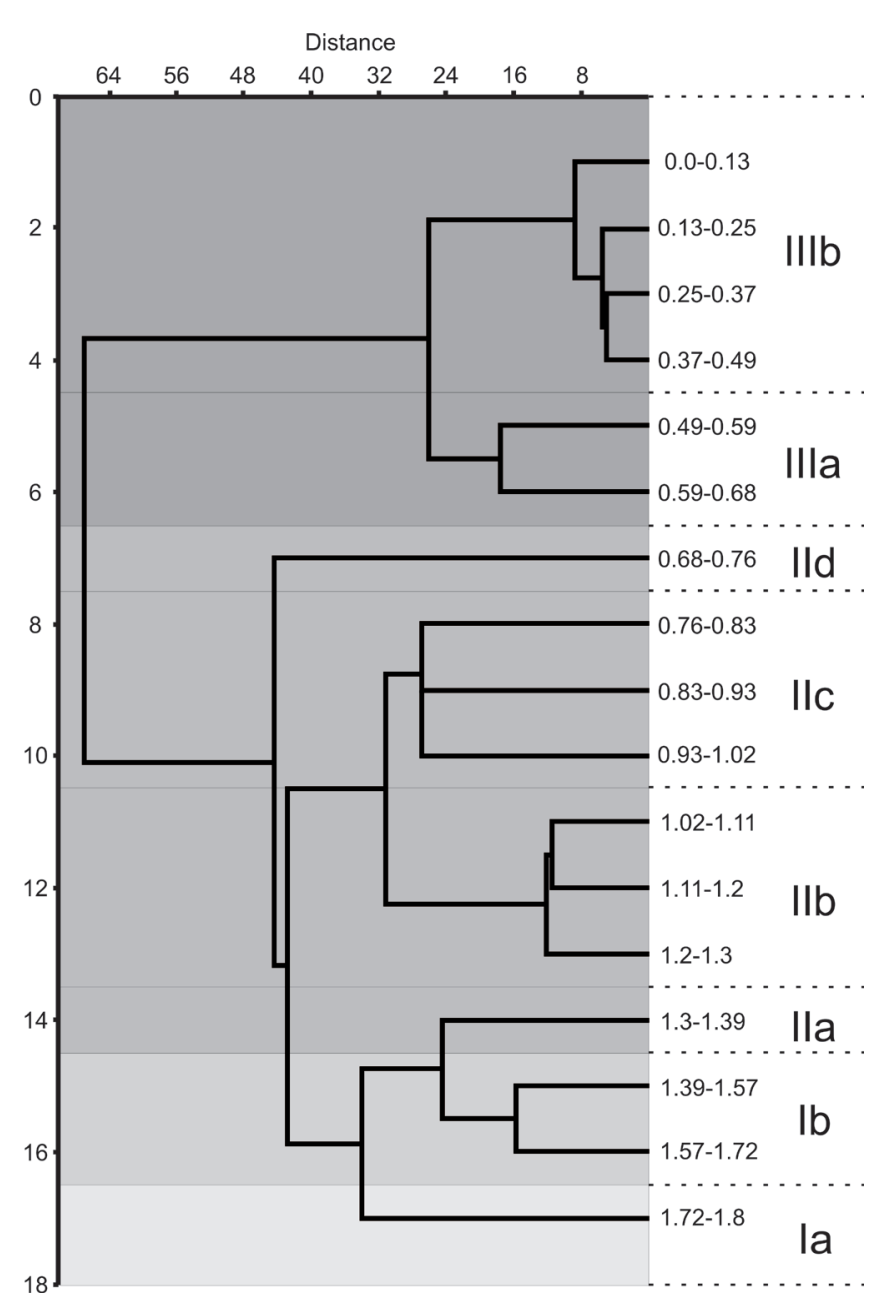

Fig. 2. Cluster analysis

that this sediment was deposited in the environment of lowered dynamics and from suspended matter of diversified grain size distribution (Fig. 4 and Fig 5). It is confirmed by poor sorting equal to 1.89 phi.

Above, to a depth of $1.41 \mathrm{~m}$, clayey sand with macroscopic plant remains occur (series Ib). Examination of plant remains derived from $1.57 \mathrm{~m}$ depth indicated the sediment age of ca. $6630 \pm 40 \mathrm{BP}$ (7507 $\pm 67 \mathrm{cal}$. BP). Analysed material shows changing content of organic matter, with $7.1 \%$ in the base of this series and $1.3 \%$ in the top. $\mathrm{C}$ and $\mathrm{N}$ content remains the same as in the previous series, while $\mathrm{S}$ is increased to $0.4 \%$. The series contain also $\mathrm{CaCO}_{3}$, at an amount of approx. $0.8 \%$ in the uppermost part. An increase in the carbon-nitrogen ratio (ca. 9) proves growing content of organic matter of allogenic origin. Grain size distribution of the series spans from 3.29 to 3.29 at very poor sorting and very positively skewed and mesokurtic distribution. Grain size distribution parameters indicate an environment of high dynamics and dominant traction deposition, with minor contribution of suspended matter.

Beginning from a depth of $1.39 \mathrm{~m}$, sandy sediment of variable grain size distribution appears, which is separated from the previous unit by a single pebble of $5 \mathrm{~cm}$ in diameter. This pebble outlines the most likely the horizon of the pebble pavement. These sands are lagoon and marine sediments (IIa-IId) deposited during the Littorina transgression. Macroremains of water plants are found in the base of the sediment (IIa), mussel fragments of freshwater malacofauna (Bithynia tentaculata, Valvata sp. Anodonta sp.) appear in the middle section (IIb), while untouched Cardium galucum occur slightly upwards (IIc). Lamination and interbeddings of organic matter and gyttja occur in the uppermost part (IId). Sand of entire lagoon and marine series is characterised by low and changing content of both organic matter and nutrients, which vary from $0.26 \%$ to $3.49 \%$ for organic matter and $0.007 \%-0.11 \%, 0.07 \%-2.24 \%$ and $0.06 \%-0.5 \%$ for nitrogen, carbon and sulphur respectively. $\mathrm{CaCO}_{3}$ content increases at first towards the top: from $0.54 \%$ (IIa) to $3.6 \%$ (IIc), whereas it is not found in the top of the series. The carbon-nitrogen ratio indicates changes in organic matter origin. Series IIa and IIc are dominated by organic matter of allogenic origin, while IIb and IId show an increase in autogenic organic matter content. Grain size distribution of the lagoon and marine series is also variable. Mean grain diameter increases from 2.35 phi (IIa) to $2.18-2.26$ (IIb) in the beginning, then decreases to $2.64-3.00$ phi (IIc) and again rises to 1.30 phi (IId). Sorting is changing from poor through moderate and well to moderately well and poor in the top. In terms of the skewness parameter, the distribution changes significantly from negatively skewed to very positively skewed as extremes, while kurtosis varies from very leptokurtic through leptokurtic and mesokurtic to leptokurtic again in the uppermost part. Grain size distribution parameters point to the fact that sediments were created from fractionated suspended matter and from rubble rolled over the bottom, in conditions of moderate dynamics and during extensive turbulences, as well as from material transported through traction in an environment of high dynamics with a lack of the possibility of precipitation from suspended matter at the same time.

The age of dated plant remains from the base $(6350 \pm 40 \mathrm{BP}-7235 \pm 69$ cal. BP $)$, Cardium shells from 


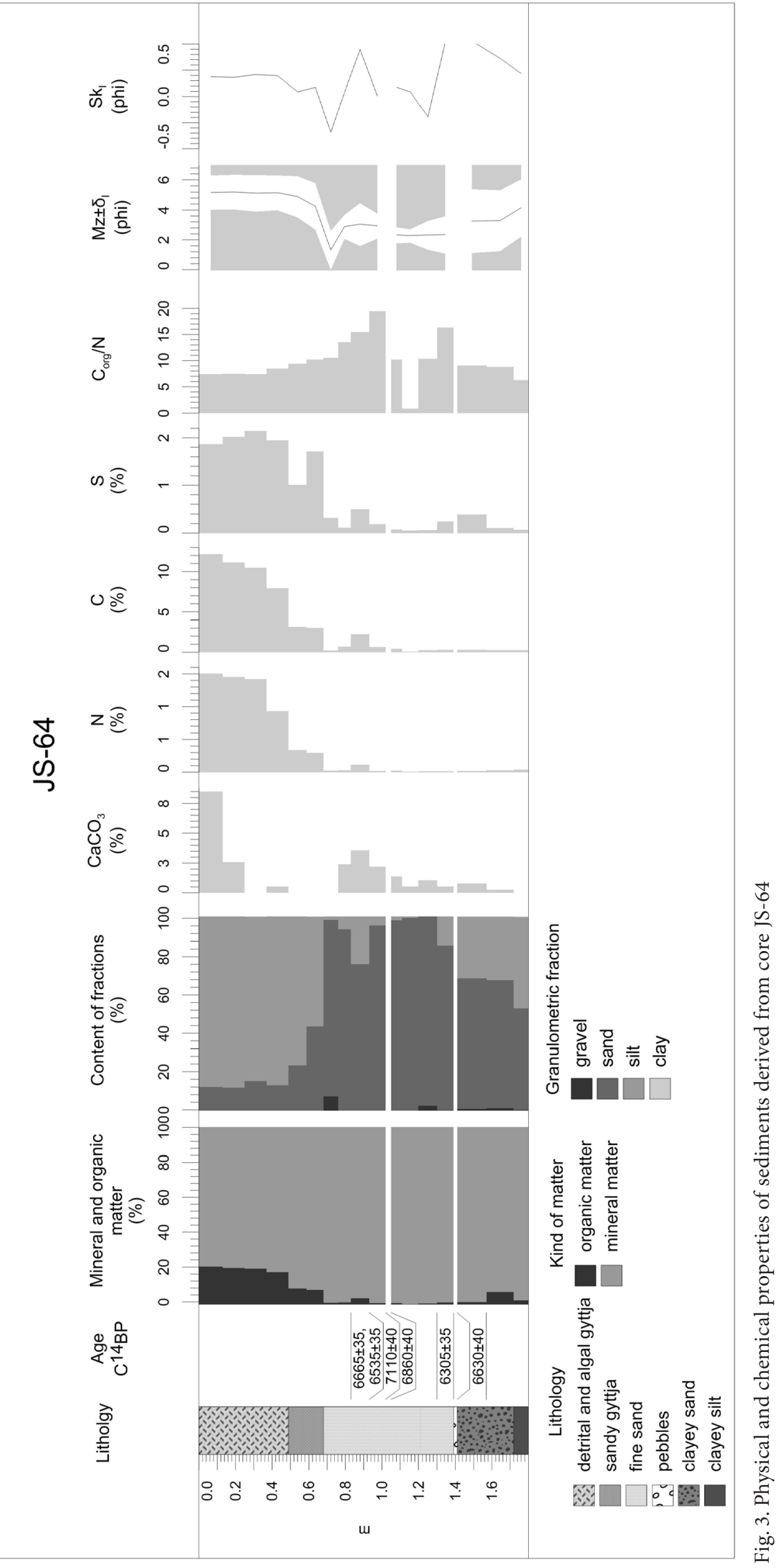




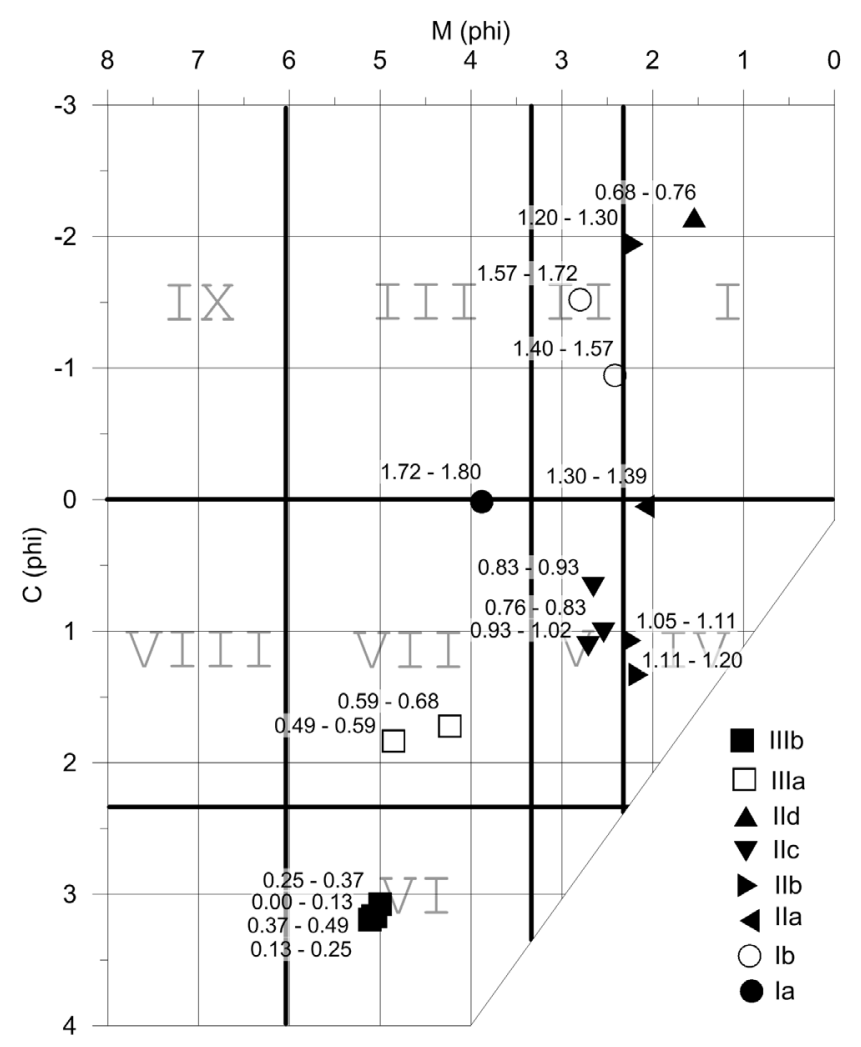

Fig. 4. C-M diagram

depths of $0.96 \mathrm{~m}$ and $1.03 \mathrm{~m}(7110 \pm 40 \mathrm{BP}-7930$ $\pm 78 \mathrm{cal}$. BP and $6860 \pm 40 \mathrm{BP}-7701 \pm 86 \mathrm{cal} . \mathrm{BP})$ and gyttja laminas from depths of $0.83-0.84 \mathrm{~m}$ and 0.93 $0.94 \mathrm{~m}(6665 \pm 35 \mathrm{BP}-7533 \pm 58 \mathrm{cal}$. BP, $6535 \pm 35 \mathrm{BP}$ - $7447 \pm 110$ cal. BP) can be associated with the high sedimentation rate of the lagoon and marine sand series. However, the age of the last samples is probably younger (because of the reservoir effect); therefore it is difficult to determine unambiguously the real sedimentation rate in the investigated period.

A change in sediment occurs at $0.68 \mathrm{~m}$. The previous series is overburdened by the post-Littorina lacustrine series, which is initially represented by sandy gyttja (IIIa). At $0.49 \mathrm{~m}$ it shifts towards fine-grained detrital and algal gyttja containing reed macroremains (IIIb). Sediments of the series reveal a gradual increase towards the top, both in terms of organic matter from $8.3 \%$ to $21.4 \%$ - and nutrients: nitrogen - from $0.29 \%$ to $1.5 \%$; carbon - from $3 \%$ to $12.2 \%$; and sulphur - from $1 \%$ to $2.1 \%$. Again, fine-grained detrital and algal gyttja contain $\mathrm{CaCO}_{3}$, which reaches $8.5 \%$ in the uppermost part. The value of the carbon-nitrogen ratio decreases as the depth increases (from 10.2 to
7.4), which can indicate change in organic matter origin from allogenic to autogenic. Mean grain diameter varies from 4.25-4.29 phi at the base (IIIa) to 5.13-5.21 in the top (IIIb). Symmetrical grain size distribution of the sediment in the base (IIIa) shifts towards positively skewed in the top (IIIb), at constant, poor sorting. Grain size distribution parameters demonstrate a significant decrease in environmental dynamics, where the sediment is created from uniform suspended matter of diversified grain size distribution.

\section{Conclusions}

Implemented studies reveal changes in sedimentological conditions in the north-eastern part of Lake Jamno, from a stage of the early Holocene limnic reservoir to the present coastal lake.

The oldest sediments of the core section were created in a water environment of low dynamics and slight primary production.

The increase in environmental dynamics occurred in the pre-Littorina phase and it turned out to be a very variable process, which is proven by an increase in mean grain diameter at simultaneous very poor sorting and changeable content of organic matter in the sediment. On the other hand, an increased content of sulphur in the top, while the content of the other nutrients is kept low, can indicate the appearance of the impact of the sea ca. $6630 \pm 40$ BP (7507 \pm 67 cal. BP) within the investigated area.

Sediments of the Littorina phase are separated from the previous series by the erosion pavement. The base of these sediments is dated to $6305 \pm 35 \mathrm{BP}$ (7325 $\pm 69 \mathrm{cal}$. BP). The sediments show significant variability, both in terms of grain size distribution and sorting. It can display extensive variations of environmental dynamics, which is probably related to the development and evolution of the spit that was gradually limiting the impact of the sea on the lagoon. Furthermore, it is confirmed by a gradual increase in calcium carbonate content and the appearance of lamination and interbeddings of organic matter in the top of the series, which certifies the periodical occurrence of calm sedimentation conditions.

The post-Littorina phase begins with sediments that are characterised by a gradual decrease in grain size at a simultaneous rapid increase in content of organic matter and calcium carbonate in the top. It indicates the moment in time, following on from which an interaction between the lagoonal environment and 

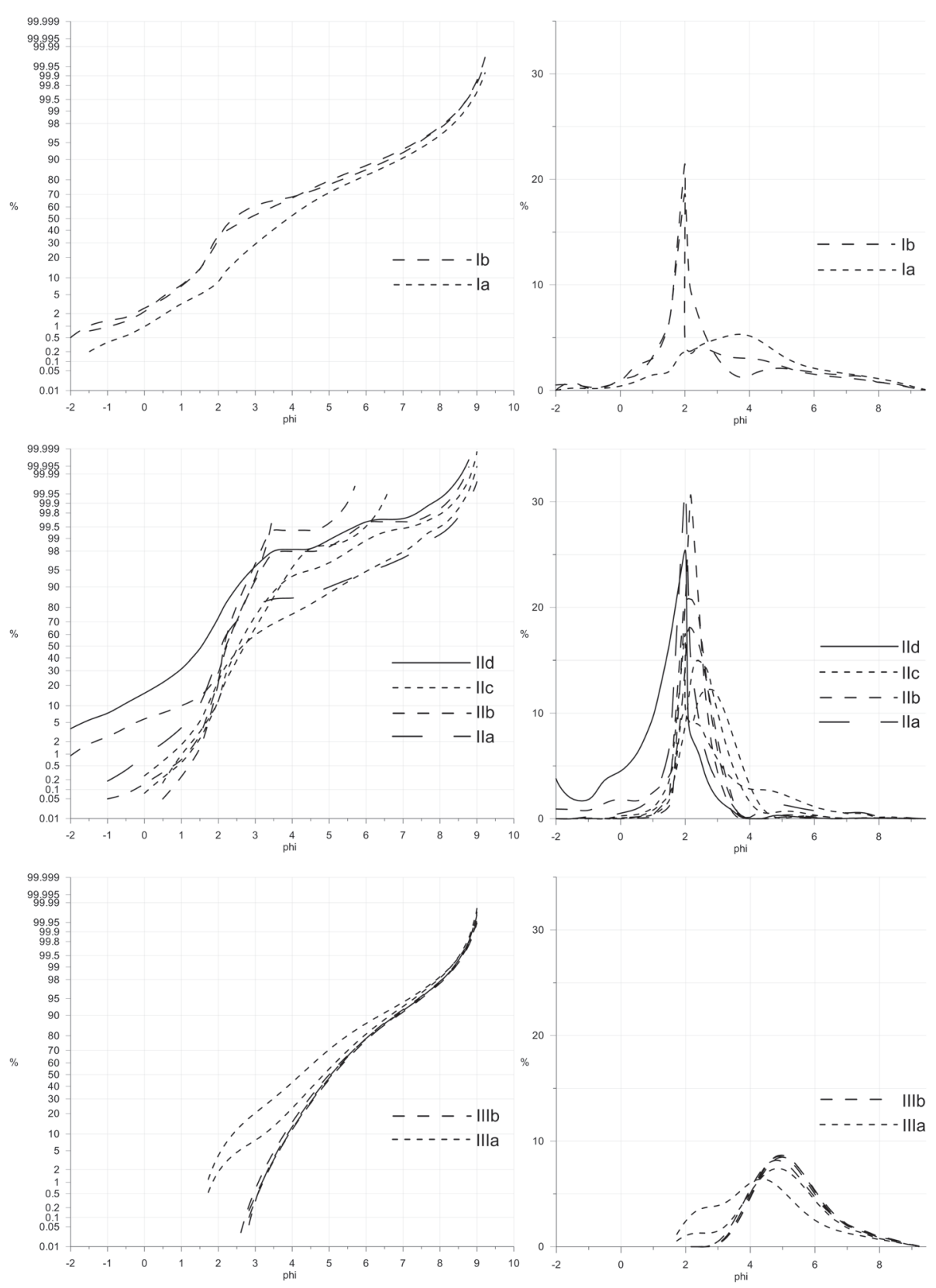

Fig. 5. Comparison of the cumulative curves and the frequency curve

sea waters became very limited and the environmental dynamics were weakened significantly. The phase set in, where conditions fostering sedimentation of mineral and organic suspended matter arose.

It should be emphasized that, in relation to the other coastal areas of Western Pomerania, the ingres- sion of sea waters during the Littorina transgression at the investigated area occurred earlier compared to the Szczecin Lagoon area (7350 cal. BP) and slightly later compared to the Rega River mouth (8300-8200 BP) (Borówka and Cedro 2010). 


\section{References}

Bieniek, B., Borówka, R. K., Tomkowiak, J., Strzelecka, A., 2013, Stratygraficzna zmienność litologii i składu chemicznego osadów wypełniających misę jeziora Jamno na podstawie profilu JS 20 (Stratigraphic variability of lithology and chemical composition fill in sediments of the basin from Lake Jamno on profile JS 20), [in:] Florek W., Geologia i geomofologia Pobrzeża i południowego Bałtyku. Tom 10 (Geology and geomorphology of coastland and southern Baltic Sea. Vol. 10), Wydaw. AP w Słupsku, Słupsk: 27-37 (in Polish, English summary).

Borówka R.K., Cedro B., 2010, Holocene marine ingressions in the coastal zone of the Pomeranian Bay based on radiocarbon assays, Geochronometria 38(1): 85-92.

Borówka R.K., Friedrich S., Heese T., Jasnowska J., Kochanowska R., Opęchowski M., Stanecka E., Zyska W., 2002, Przyroda Pomorza Zachodniego (Nature of the Western Pomerania), Oficyna In Plus, Szczecin, pp. 56 (in Polish).

Borówka R. K., 2007, Geochemiczne badania osadów jeziornych strefy umiarkowanej (Geochemical research on lacustrine deposits in the temperate zone), Stud. Lim. et Tel. 1(1): 33-42 (in Polish).

Dąbrowski, M. J., Lubliner-Mianowska K., Zachowicz J., Wypych K., 1985, Z Palinologii osadów Jeziora Jamno (Bottom sediments of Lake Jamno in the light of palynological studies), Peribalticum 3: 37-52 (in Polish, English summary).
Folk R.L, Ward W.C., 1957, Brazos River bar: a study in the significance of grain size parameters, J. Sedim. Petrol. 27: 3-26.

Miotk-Szpiganowicz G., Zachowicz J., Uścinowicz Sz., 2007, Nowe spojrzenie na rozwój zbiorników przybrzeżnych południowego Bałtyku (New views on the development of coastal water bodies at the Southern Baltic), Stud. Lim. et Tel. 1(2) 127-136 (in Polish).

Osadczuk A., 2004, Zalew Szczeciński. Środowiskowe warunki współczesnej sedymentacji (Szczecin Lagoon. Environmental conditions of current sedimentation), Ser. Rozpr. i Stud. 549, Wydaw. Nauk. US, Szczecin, pp. 157 (in Polish, English summary).

Przybyłowska-Lange W., 1979, Diatoms of the lake deposits from the Polish Baltic Coast. II lake Jamno, Acta Paleobot. 21(2): 227-244.

Passega R., Byramjee R., 1969, Grain-size image of clastic deposits, Sedimentology 13(3-4): 233-252.

Racinowski R., Szczypek T., Wach T., 2001, Prezentacja i interpretacja wyników badań uziarnienia osadów czwartorzędowych (Presentation and interpretation of the results of grain-size analysis of the quaternary deposits), Wydaw. UŚ, Katowice, pp 145 (in Polish). 
